\title{
Populisme hitter - både blandt vælgere og politologer
}

\section{En kommenterende anmeldelse af Jan-Werner Müller, Cas Mudde og Christobal Kaltwasser samt Ernesto Laclau}

Ernesto Laclau, 2014

Redigeret af David Howarth

Post-Marxism, Populism and Critique

Routledge, London

249 sider, 439,95 kroner

Cas Mudde og Christobal Rovira Kaltwasser, 2016

Populism. A Very Short Introduction

Oxford University Press, Oxford

136 sider, 99,95 kroner

Jan-Werner Müller, 2016

Hvad er populisme?

Informations Forlag, København

179 sider, 249 kroner

Anmeldt af Carsten Jensen, ph.d. i statskundskab

Populismen har ryddet forsider i de senere år. Med valget af Donald Trump, en antielitistisk, men autoritær populist som USA's præsident nåede den sit foreløbige højdepunkt i 2016. UKIP's succes med at få briterne til at stemme gang i en udmeldelsesproces i forhold til EU var også med til at sikre fremdrift. På den anden side talte dog, at Marine le Pen overbevisende tabte det franske præsidentvalg og siden meldte ud, at de franske vælgere havde overbevist hende om, at vejen frem for franskmændene ikke går uden om EU.

De tre sæt af begivenheder har hver på deres måde været med til at gøre populismen til et populært valg som medietema og til at vise, at populister kan sætte dagsordner - også for eksperterne. Der er samtidig begyndt at komme mange bøger om net- 
op populisme. Her er valgt tre, der hver på deres måde er karakteristiske for nogle bredere strømninger i politologisk, politisk og idéhistorisk litteratur. Ernesto Laclau skrev siden begyndelsen af 1970'erne om populisme og dens konflikter med liberalisme, Cas Mudde har mange år på bagen som en af de mest anerkendte politologiske populismeforskere, mens Jan-Werner Müller, der primært har været kendt for sine bøger om demokratiet og dets udfordringer i et ideologiteoretisk perspektiv, er relativt nytilkommen på populismescenen. Tilsammen giver de et bredt billede af populismens politiske, empiriske og teoretiske udfordringer til politologer samt eksempler på, hvordan man kan møde dem.

\section{Bøgernes særtræk}

Set fra et strikt statskundskabsperspektiv er Cas Muddes og Cristobal Rovira Kaltwassers lille bog Populism. A very Short Introduction den mest centrale af de her valgte tekster. Den former sig som en relativt nøgtern indføring i emnet, der ikke i første omgang bjergtages af emnets aktualitet, men i stedet giver en bred oversigt over populismens udvikling. Forfatterne inkluderer dels den populistiske realitet fra det 19. århundredes russiske folkevenner til vores dages europæiske højrepopulister samt latinamerikanske venstrepopulister, og dels de tilgange, der har været med til at uddybe kendskabet til dem.

Populism giver desuden en oversigt over nogle af de større debatter, der er blevet fremprovokeret af populismens succes. Der er kapitler om populistisk lederskab, populisme og demokrati, årsagerne til populisme og endelig spørgsmålet om, hvad man kan og skal gøre ved den. Hvad angår det sidste, mener Mudde og Kaltwasser, at populismen i de aktuelle former har været med til at sætte reelle politiske og sociale udfordringer på dagsordenen. Blandt de emner, hvor man bør lytte til populisterne, er 'det demokratiske underskud i EU' og ulighed i Latinamerika. De hævder, at det bedste værn mod populister på sigt er at fjerne årsagerne til 'den populistiske efterspørgsel'. Det vil f.eks. sige at demokratisere EU og afbøde de værste uligheder.

Jan-Werner Müllers Hvad er populisme? er på sin vis 'nøgtern' nok, men den er først og fremmest et meget passioneret debatindlæg mod populisme. Hvor Mudde og Kaltwasser anerkender, at 'populisme' kan være nyttig i nogle sammenhænge, som for eksempel når autoritære samfund skal demokratiseres, går Müller all in i angrebet på populister. I hans optik er populisme ganske enkelt 'anti-pluralistisk' og tendentielt antidemokratisk. Hvad er populisme? former sig da også som en kritisk diskussion af aktuel populisme i tre dele: En diskussion af teorier om populisme, en diskussion af den reelt eksisterende populisme, især i Europa i det nye årtusinde samt en diskussion af, hvad man kan gøre ved den.

Hvor Mudde og Kaltwasser går overvejende politologisk til værks er Müllers tilgang mere idéhistorisk, og han fokuserer især på de direkte politiske effekter af populisme. Det betyder bestemt ikke, at han mangler sans for realiteter og detaljer, men blot at den politiske hensigt om at komme frem til, hvordan man bekæmper populisme i det 
hele taget, øjensynligt har fyldt mere i tilvejebringelsen af bogen og dens disposition, end den har gjort for de førstnævnte. Også for Müller er svaret på populismens udfordring dog mere demokrati. Populismen skal bekæmpes med demokratiske midler, og liberale demokrater skal utrætteligt indgå i dialog med populisterne.

Mens de to nævnte bøger bevidst er skrevet som enkle oversigter over emnet er Ernesto Laclaus bidrag mere subtilt. Det er på sin vis ligeså repræsentativt for en strømning - diskursteori og tilgrænsende tilgange, men det er ikke så tilgængeligt og heller ikke skrevet så direkte formidlende. I stedet findes Laclaus 'seneste populismebog' skjult inden i det udvalg af repræsentative tekster fra hans hånd, som David Howarth redigerede for forlaget Routledge i 2014. Samlet set udgør fire af kapitlerne, skrevet fra 1977 til 2007, en tekstmasse af samme omfang som de øvrige nævnte bøger, der behandler populismen.

Ernesto Laclau publicerede sin første tekst om populisme på engelsk i 1970. Her blev 'populisme' set som den politiske form, som modstanderne af Argentinas (hans hjemlands) oligarkier påtog sig i kampen mod, at landets økonomiske politik blev underlagt krav fra verdensmarkedet i stedet for dets indbyggeres behov. Laclau formulerede sig dengang inden for marxismens rammer, men forlod denne tankegang i begyndelsen af 1980 'erne. Hans oprindelige tilgang til populismen blev dog udviklet som en tilføjelse til marxistisk politik- og ideologiteori og offentliggjort som en del af hans ph.d.-afhandling fra Oxford i 1977. De tekster om populismen, der er samlet af Howarth, dækker både den marxistisk og den post-marxistiske periode, og de giver således en bred indføring. Også Laclau har naturligvis drøftet, om man skal støtte eller modarbejde populismen. Som Mudde, og i stærk modsætning til Müller, ser han nærmest populismen som sådan som en politisk neutral form, men tilslutter sig selv eksplicit et venstrepopulistisk synspunkt.

Det klassiske spørgsmål: Hvad er populisme?

De valgte bøger har til en vis grad hver deres svar på problemet angående populismens egenart, men er mere enige om mange af dens karakteristikker, end man umiddelbart skulle tro.

Cas Mudde har kaldt sin tilgang ideologisk orienteret, til forskel fra tilgange, der ser populisme som politisk stil, et rationelt valg for landbrugere i overgangen til industrisamfund eller simpelthen en ultrahøjre-bevægelse.' Mudde og Kaltwasser (s. 6) definerer populisme som en "thin-centered ideology that considers society to be ultimately separated into two homogenous and antagonistic camps, 'the pure people' versus 'the corrupt elite', and which argues that politics should be an expression of the volunté generale (general will) of the people."

\footnotetext{
'De kalder deres tilgang til populisme "an 'ideational' approach", concieving it as a discourse, an ideology, or a world-view." (s. 5).
} 
Denne definition ligger snublende tæt på Ernesto Laclaus (s. 132)² fors $\emptyset$ g fra 1977, som er genoptrykt i Howarths udvalg: "Our thesis is that populism consists in the presentation of popular-democratic interpellations as a synthetic-antagonistic complex with respect to the dominant ideology."

Hovedelementerne i de to tilgange er fuldt ud forenelige omkring forestillingerne om 1) en dikotom samfundsopfattelse, 2) et over- og et undersamfund og 3) en kollektiv vilje, der modsætter sig status quo under påberåbelse af at repræsentere folket mod eliten. Til denne enighed kommer, at Jan-Werner Müller (s. 42-43) også anerkender formuleringerne i grove træk, om end dog kun som sekundær karakteristik, ikke som definition: "Populisme er efter min tese en ganske bestemt forestilling om politik, hvor det moralsk rene og homogene folk altid står overfor umoralske, korrupte og parasitære eliter - hvoraf følger at denne type eliter i virkeligheden slet ikke hører til folket".

Til forskel fra den 'ideologiske' opfattelse af populisme, som karakteriserer de to førstnævnte tilgange, skal det fremhæves, at Jan-Werner Müllers grundidé om populisme adskiller sig. Müller vil udvikle en 'idealtype', der entydigt kan placere politiske ideer og især politikere inden for 'populisme-kategorien'. Müller (s. 25-26; 19) finder sit kriterium i ideen om, at nogle ikke accepterer pluralisme i en demokratisk kontekst, men hævder at have en privilegeret adgang til/et moralsk monopol på at repræsentere 'folket': "Det jeg gerne vil betegne som alle populisters kernepåstand, lyder omtrent sådan: 'Vi - og kun vi - repræsenterer det sande folk.'”. Det formuleres også sådan: "Populister påstår 'Vi er folket'. De mener imidlertid - og det er altid et moralsk og ikke et empirisk udsagn (...)' Vi - og kun vi - repræsenterer folket'.'

Hermed følger også en anden af Müllers sekundære påstande om populismen, nemlig at den er anti-pluralistisk, fordi den ikke anerkender andres krav på også at repræsentere folket, eller i det mindste dele heraf, og dermed også bliver tendentielt udemokratisk, fordi populister $\emptyset$ nsker selv at regere uden bindinger til de demokratiske spilleregler i øvrigt.

Som det fremgår, er de to typer definitioner gensidigt udelukkende. De medfører da også to forskellige former for politisk vurdering. Mudde og Laclau ser populisme som en i princippet 'neutral' politisk form, der altid vil blive indholdsudfyldt (til højre eller venstre), mens Müller ser den som direkte partisk, anti-pluralistisk og tendentielt anti-demokratisk.

\footnotetext{
${ }^{2}$ I en anden tekst fra samme år skriver Laclau om den populistiske konflikt: "Through this antagonism, the dominated sectors would ... identify themselves ... as 'the other', 'the counterposed' to the dominant powerbloc, as the underdog." - svarende til det Mudde og Kaltwasser beskriver som "”the pure people" versus "the corrupt elite". Ensartetheden i formuleringerne er om end ikke ord for ord, så dog indholdsmæssigt helt parallel. Hvis man dertil lægger Muddes og Kaltwassers formulering om 'volunté generale' og sammenligner den med Laclaus optagethed af 'collective will', som del af udformningen af hegemoniske projekter for henholdsvis magtblok og underhunde, er det strengt taget svært at se forskel på de to tilgange. Citatet er fra Ernesto Laclau (1977) Politics and Ideology in Marxist Theory. Verso, London, Verso, s. 107.
} 


\section{Er problemet så 'højre' eller 'populisme'?}

Laclau har siden 1977 udviklet sin populismeopfattelse i den retning, at al politik i demokratiske samfund har populistiske elementer i sig. Der vil altid være en vis mængde påkaldelse af at 'repræsentere folkelige kræfter' i demokratisk politik, uanset hvordan dette så måtte blive formuleret i praksis, og hvad enten det er fra højre eller venstre. Denne antagelse modsiger naturligvis tilgange som Müllers, mens Mudde og Kaltwasser i langt højere grad er villige til at drøfte populismens eventuelle dyder (se følgende). Mere specifikt føjer Laclau også en slags idealtype til sin tilgang, nemlig den tanke, at den typiske populisme opstår i heterogene samfund, skaber en enhed af krav fra neden, skaber symboler for denne enhed og som regel frembringer en leder, der kan fortolke kravene for 'folket'. Jo flere træk af denne beskrivelse en given politisk bevægelse har, jo mere rendyrket populistisk er den. Der er imidlertid ikke noget i typen, der i sig selv skulle pege på en særlig højre- eller venstredimension.

Hvad Laclau angår, har hans store interesse dybest set altid været venstrepopulisme, eller måske snarere mulighedsbetingelserne for, at venstrepopulistiske bevægelser kunne udvikles og trives. I den forstand er problemet entydigt højre-egenskaben ved visse bevægelser - ikke deres eventuelle populisme. I en lille spansksproget tekst fra 2005 drøftede han da også det, han så som de vigtigste partier i udviklingen af et alternativ til neoliberalismen, nemlig de latinamerikanske 'centrum-venstre' populister, hvortil han regnede et så bredt felt som Kirchner-parret i Argentina og Hugo Chavez i Venezuela. Imidlertid lå han helt på linje med Mudde og Müller, når de ser højrepopulismen som den henholdsvis empirisk og principielt set største politiske udfordring af de to varianter.

Mudde og Kaltwasser bruger 17 linjer og en illustration ud af Populisms 130 sider på den aktuelle europæiske venstrepopulisme, Syriza og Podemos. Det er bestemt ikke her, de ser den store udfordring - hverken til det liberale demokrati eller til politologien. Den egentlige udfordring i USA og Europa kommer i deres optik fra højrepopulismen. Ofte er det da også sådan, at populisme og højrepopulisme bruges som synonymer. Det gælder for eksempel for Jan-Werner Müller, der nærmest skal til Latinamerika for at finde en virkelig venstrepopulisme, den venezuelanske chavisme, mens han egentlig ikke ser Syriza og de selverklærede venstrepopulistiske ledere af Podemos (Pablo Iglesias og Enigo Errejón) som populister i hans forstand.

I praksis definerer Mudde og Kaltwasser (s. 34) højrepopulisme som en kombination af populisme samt autoritære og nationalistiske politiske ideologier. Hvad angår den autoritære dimension peger de på "'law and order' issues" og med hensyn til den nationalistiske dimension på den forestilling at "states should be inhabited exclussively by members of the native group ("the nation") and that non-natives ("alien") elements are fundamentaly threatening to the homogenous nation-state." De opfatter tilsvarende Jean-Marie Le Pens parti Front National fra 1972 som prototypen på denne politiske form. I praksis mener de (s. 34) dog, at højrepopulisme først blev en relevant politisk kraft i Europa i 1990erne. Man kunne tilføje: Altså efter Murens Fald og i takt med at 
den nye verdensordens globalisering i stigende grad blev mærkbar. Som dansker kan man godt føle sig lidt overset, når de svinger den brede pensel. Fremskridtspartiet var trods alt blandt de store stemmeslugere i 1970'erne.

Sammenligninger, styrker og svagheder

I de tre valgte udgivelser former vurderingerne af populisme sig i et ret komplekst mønster. Som det er fremgået, er der i udgangspunktet store ligheder mellem definitioner fra Muddes og Kaltwassers samt Laclaus side. Müller kan også tilslutte sig indholdet i definitionerne, men kun som underordnet beskrivelse, idet han selv foreslår en definition i en helt anden dimension.

Også med hensyn til vurderingen af forholdet mellem populisme og den klassiske politiske kløft i økonomisk interessebaseret politik synes Laclau samt Mudde og Kaltwasser at være enige: Populisme kan være både være højre- og venstreorienteret. Denne opfattelse udfordrer i praksis Müllers formuleringer, der synes at se populismen som tendentielt højreorienteret.

Endelig står Müller også lidt alene med ideen om, at populismen af natur er 'anti-pluralistisk' og tendentielt anti-demokratisk. Mudde skriver derimod nuanceret og meget eksplicit, at populisme kan være en løftestang for demokratisering af autoritære samfund, men at den som regel trækker i den modsatte retning i udviklede, liberale demokratier. Den er en illiberal demokratisk bevægelse, der ofte er rettet mod udemokratisk liberalisme. Hermed kunne man uden at gøre vold på forfatterne sige, at i forhold til 'det demokratiske underskud' i EU, er det måske meget sundt for demokratiet med noget populisme og elite-kritik. At lade andre stemmer end ministerråd og teknokrater blive hørt i EU debatten er ikke 'anti-pluralisme', selvom disse stemmer skulle påkalde sig at være 'folkets røst'.

Til slut en opsummerende forbrugeroplysning. Muddes og Kaltwassers bog bør roses for det bredeste udsyn, det største overblik og det bedste udvalg af tekster, der anbefales til videre læsning. Nogle steder er der dog nok valgt en lidt for bred pensel i fremstillingen, men den giver klart det bedste afsæt for videre empiriske studier.

Ernesto Laclaus tekster bør roses for at opsummere den længste erfaring og for at være de mest originale. Hans tekster præges dog nogle gange af indforståethed og for meget fokus på 'fikse ideer'. Laclau er i denne sammenhæng tyk på filosofi og teori, men noget tynd på empiri.

Jan-Werner Müllers bog er i særklasse bedst skrevet, men der er lidt for meget namedropping og politisering end systematisk empiriske henvisninger (selvom der er mange eksemplificerende henvisninger til populistiske synspunkter, bevægelser og partier) - hvor sympatiske hans liberalt-demokratiske synspunkter end er.

Man kan ikke på den baggrund pege på en tekst frem for de andre. Men hvis man zoomer ind på enkelte aspekter, kan man sige, at fra et teoretisk synspunkt vinder Laclau for sin grundighed, fra et empirisk vinder Mudde og Kaltwasser for deres solide 
greb om den reelt eksisterende populisme. Praktisk politisk vinder Müller for hans gennemtænkte liberaldemokratiske argumenter mod (især højre-)populisme.

Alt $i$ alt er der i hvert fald masser af stof i de tre bøger til fortløbende debat og oplæg til videre arbejde i alle dimensioner (teoretiske, empiriske og politiskideologiske). Syntese er nok umulig endnu, men det er efter alle tre forfatteres mere eller mindre eksplicitte værdigrundlag sikkert meget sundt. Et vist mål af uenighed, så længe der også er et vist mål af fælles grund, er nyttigt i den demokratiske debat og vidensudvikling - også med hensyn til populismen. 